\title{
Comparative analysis of Editorial treatment by Urdu Press of Pakistan regarding Elections 2008
}

\author{
Saima Zareen1, Rubab Fatima2, Dr Arshad Ali \\ Department of Communication Studies and Media Center, University of Gujrat, Pakistan
}

\begin{abstract}
The research makes a comparative analysis of editorial treatment of election 2008 in Pakistan, with reference to Benazir Bhutto's assassination. The study presents content analysis of 2002 editorial from Daily Express ,Daily Jang and Daily Nawa-E-waqat during six month times period, from 18,Ocober,2007 to 18,April,2008. The study establish that in first two months of coverage before Benazir Bhutto 's assassination, all the news paper had a diverse opinion about favorite political party in 2008 election campaign .In the second phase, after Benazir Bhutto s' assassination, all the news paper had changed their opinion and favored Pakistan people's party. In third phase coverage remain same as second phase. Agenda setting theory and frame model provide a theoretical framework for the study. Agenda setting theory provides a ground to compare the era wise coverage. The selected era is divided into three time periods.(1) Pre assassination(2) Post assassination(3) Post election. Result indicates that public agenda can be affected by media agenda. The study shows that election 2008 result was very similar to news papers and party wise coverage. All those parties won more seats in parliament which were covered as a favorite party in news papers. It is quantitative as well as qualitative research, counts the variables and also measured the favorable, unfavorable or neutral point of view about those variables. Total time period is selected as sample is six month. It is further divided into three sets. Favorable, Unfavorable and Neutral.
\end{abstract}

Keywords: Comparativeanalysis,Election2008,Assassination,Media Role, Editorial treatment ,Opinion formation, Political party.

\section{Introduction}

Some incidents occur in the history of nations that change the whole scenario of the world .Same as some personalities also have such importance among nations. Benazir Bhutto is a fine example of this. Benazir Bhutto was born ( 21 June 1953-27 December 2007) in politician family known by Pakistan people's party (ppp), a center left and the largest political party in Pakistan ,Benazir Bhutto was the first and to date only women elected prime minster of any Muslim state .Benazir was elected as prime Minister for the first time in 1988 at the age of 35,but was removed 20 months later under the order of President Ghulam Ishaq khan on grounds of alleged corruption. In 1993 She was re-leased but was again removed in 1996 on similar charges, this time by her party elected President Farooq Legari .She went in to self -imposed exile in Dubai in 1998. She returned to Pakistan on October18, 2007.She was assassinated on 27 December 2007. The following year,she was named one of seven winners of the United Nation prize in the field of human rights. After the assassination, disturbance was up rising, in result approximately 20 deaths occurred ,there were three of them were police officers, Around 250 cars were burnt, angry and upset supporters of Bhutto threw rocks outside the hospital where she was being held. Nine ruined election offices, 176 banks , 34 gas stations, 18 rail stations ,and hundreds of shops. President Musharraf pronounced the three-days period of mourning.(2007)

\section{Before death of Benazir Bhutto.}

\section{Assassination effects on elections:}

Punjab has 148 out 272 NA contested seats PML(Q) was predicted to get around 80 to 90 seats in Punjab alone (death of BB cost them around 62 seats shortfall from prediction as they got only 28 seats ... check prediction change after death of $(\mathrm{BB})$

\section{After death of Benazir Bhutto.}

It was expected that PPP might increase their vote bank by at least 10 percent and the party that would get most effected would be PML (Q).PPP was predicted to get around 110 NA seats out of 272 contested seats (they got 89)... a shortfall of 21 NA seats.PML (N) was predicted to get around 62 NA seats out of 272 contested seats (they got 67).... a gain of 5 seats.PML (Q) was predicted to get around 42 NA seats out of 272 contested seats (they got 42)..... exact number as predicted. Independent experts believed [before assassination] that PML (Q) could hardly win 80 to 90 NA seats in Punjab. However Benazir Bhutto's assassination had changed expert opinion because of the sympathy vote for PPP.... Technical view about the forth coming 
elections is the percentage calculation of sympathy vote for PPP. Assuming that it adds 10 percent votes to PPP's existing vote bank, the party can easily win 110 seats out of 272 seats in the parliament based on 2002 statistics PML (Q) and (N) 42 and 62 seats respectively.1.(SAN 2008)

\section{Role of Media}

The media always play a significant role to inform the citizen about the competing political parties.. Media also contribute the opinion formation of the voters..Communication research provides evidence that the news media is a primary agent of agenda. An issue that is covered by the new media that how the public reacts in public opinion polls and how policy makers will respond through legislation .Agenda setting also refers to the ability that the media not only reflects reality but also determine reality that how much attention will be payee by the public on any particular issue

\section{Research Objectives:}

1. "How media change the opinion of audience?"

2. It is a fact that media is a powerful tool to build any perception in our daily life, but how it can change our existing perception and opinion?

3. How media divert attention towards a specific direction?

\section{Research Question:}

1. Which was the favorite political party before Benazir Bhutto's assassination?

2. What was the opinion of every newspaper under study about favorite political party in pre assassination era?

3. What was the change occur in news paper editorial coverage regarding election 2008, after assassination?

4. What was the difference occur in opinion after election?

\section{Significance of research}

As discussed above that assassination of Benazir Bhutto is a very important incident in the national history of Pakistan. It has opened the new gateway for social sciences researchers: Opinion and opinion change is a whole phenomenon that is involved in this incident. Before Benazir assassination, Public opinion regarding election was different but after B.B assassination it has been changed. Media is an intervening variable in the process of opinion change it played a vital role in everybody life. It plays very important role in opinion making and opinion change. This research will help to know media plays its role in the process of opinion making and opinion change in some specific circumstances.

\section{Literature review:}

Comparative analysis of editorial treatment is a popular research in media studies. A large number of researchers have performed this analysis regarding different topics. Benazir assassination is also a very important incident in the history; many experts have written articles on different dimension on this incident .Some of them relevant to this study are following.

2. (Election.com 2008)The article is written before election 2008 and after Benazir Bhutto's assassination .In this article, expectation of different political parties are discussed briefly with their past election records.In this article it is said that president of Pakistan Muslim league (Q)Ch Shujahat Husaain had claimed before Benazir Bhutto 's assassination that his party would win 110 out of 148 national assembly seats in Punjab. But in the mean while, independent experts believed that Pakistan Muslim League (Q) could hardly win 80 to 90 seats. After Benazir assassination Pakistan Muslim League (Q) thought that sympathy vote is limited to urban population only and it is going to affect Pakistan Muslim League (N) Pakistan Muslim League (Q) (Pakistan Peoples' party has been getting at least 18-20 percent votes at an average and if a good candidate fetches 15 percent votes with personality cult, the seat could be safely won. The party can easily win 110 seats out of 272 seats in the parliament based on2002 statistics. Pakistan Muslim League (Q) and (N) can win 42 and 62 seats respectively.

(Sharma Delhi)He says that the future of Pakistan is totally unpredictable because U.S had been trying to reconcile Benazir Bhutto and Pakistani President Pervaiz Mushraf .B.B's death has changed the whole scenario .The United States wanted to conduct an election must be free and fair. For the Mushraf Government to tackle Jihadists is very difficult. Pakistani's and U.S pressure on Mushraf to restore democracy in Pakistan .Bhutto's death has certainly affected the game plan of the U.S. But the U.S cannot leave nuclear Pakistan into the hands of the Taliban or other anti U.S forces. The debate in the U.S over Pakistan is in favor of civil society in Pakistani politics. Bhutto's death has disturbed the camping of 8 January Parliamentary elections and the process of restoration of democratic Government and Election may be postponed for a few weeks. B.B's husband and son took control of Party. Sympathy environment was developing in the favor of people's party. 


\section{Here are some research articles reviewed which are related to comparatively analysis of editorial treatment regarding different cases:}

(Somia Shakirl) The research article is a comparative analysis of editorial treatment on Indo Pak conflicts. In 1947 Sub-content was divided in to two independent countries Pakistan and India. Pakistan had two arms, East and West. After Independence India and Pakistan established diplomatic relations. This research explores a comparison of war and peace framing in editorials of "Daily Down" and "The Nation "In coverage of Indo pak conflict. The study presents content analysis of 107 editorials from both dailies during 6 months time period during July - December 2009. The result clearly shows that the editorials of News papers are highlighting the terrorism issue and ignored Kashmir dispute and water issue or given less coverage then other issue. Media should encourage peace process in a neutral way for the development and betterment of the region. As war is not the solution of this conflict. War is completely harmful and just destruction for both of the neighbor country. Media must portray all the conflicts in the positive way and play a key role to promote friend ship and do possible negotiation between the countries instead of promoting war journalism and show up the issue in the negative way which only direct to both countries towards war.

Richardson at al. A content analysis of U.S Newspaper editorials $(\mathrm{N}=158)$ examined framing of Supreme Court ruling on affirmative action at the university of Michigan. Framing is a concerned with efforts to shape perceptions of an issue through selective use of words and image. This study examined framing of the Gratz and Grutter decision by analyzing responsive newspaper editorials. In contrast to prior content analysis, result here showed the emergence of an alternative way to frame affirmative action.

Sikanku ,Etse (2010) In summer 2009 ,Barak Obama first time visited to Sub-Saharan Africa as President. His visited to Ghana " a former slave producing country" from July 10-11 was as historic as his fall 2008 election .This study examined how African ( The daily Graphic, The Daily Nation ,All Africa .com )and non- African news media (The times ,the New York times, associated press)covered Barrak Obama's first visit to Sub Saharan Africa ( Ghana).A content analysis 163 stories found five major themes embedded in media reportage of America's first black president visit to the continent of his father country. This includes globalization, Democracy, responsibility, historical and soft news narratives. The African Newspaper concentrated more on the historical and soft news frames while non African News papers reported heavily on the Democracy and responsibility frame.

Chang ,yu-li,and chang,kuang -kuo. (2003) September 11 terrorist attacks on the World Trade Center and the Pentagon shocked the Americans and other world. This incident and its outcome dominated the news headline in all U.S media. According to Eilders and Lutter, framing strategies must be clear in political editorials since editorials writers do not have to follow the norms of objectivity and editorials were written to express opinions on important issues. The concept of "framing" has proved the importance in the dominion because mass media actively set the frames of reference that readers use to interpret and to discuss news. The purpose of this study to link these two apparently separated areas of research."framing analysis and factors of international media coverage "and find out whether extrinsic factors affected the frames adopted by international newspaper editorials when starting the September 11 terrorist attacks. This study includes two sets of data content analysis of editorial frames based 37 English news paper editorials from 26 countries :and extrinsic (context -related )news factors and international communication research .Extrinsic (context -related )factors as independent variables to measure their certainty of the dependent variables(editorialsframes) September 11 attack put huge impact on worldwide news coverage and editorials. For the analyst it was the excellent opportunity to express and communicate their opinion on this incident through communication.

\section{Theoretical frame work:}

Agenda Setting theory: Agenda setting theory emerges from communication studies and focuses on mass media impact on political agenda setting.Prof Maxwell Mccombs and prof Donald Shaw had developed agenda setting theory in the chapel hill, election in 1968.

Frame model: Framing is a concept related to media researchers, according to this concept media has focused on a specific issue and highlighted some features on media .

\section{Conceptualization:}

In the research discuss the role of news paper to make public opinion. How media make and change public opinion? The question is related to agenda setting theory. Agenda setting theory says that media sets public agenda towards a specific direction. In the research editorial coverage is divided into three frames.

1.Favourable

2.Unfavourable

3.Neutral

Which frame has used in editorials? There are symbols that are used for coding (1) for favorable (0)for unfavorable and (-)for neutral coverage. The research is a content analysis of newspaper editorials. Popularity of 
different political parties is to be measured in three era's. Pre assassination, Post assassination and Post election. A comparative analysis of the editorial coverage in these three eras will find the media agenda about issue.

\section{Operationalization :}

Comparative analysis of editorial treatment by Urdu press of Pakistan regarding election 2008 will be analyzed with coding frame. Coding frame is developed with categories which will be analyzed in the research

Hypothesis

\section{Pre Assassination:}

$>$ Pakistan people's party, Pakistan Muslim league (Nawaz)and Pakistan Muslim league (Q)were the most popular parties in editorial coverage.

2. All the understudy news paper had diverse opinion about popular political parties.

\section{Post Assassination:}

$>$ After assassination of B.B favor rate of Pakistan people's party had increased in three newspapers.

$>$ Pakistan Muslim league (Q) had lost its popularity after assassination of B.B.

3.Post Election:

$>$ After election all the parties with minority had favored Pakistan people's party.

\section{Research Methodology}

Content analysis method is be used in the research. It is a comparative analysis of editorials published in different newspapers during election 2008 campaign in Pakistan, Benazir Bhutto assassination who was the famous opposition leader had changed the whole environment of election in the country. This is a conceptual analysis of popularity of different political parties in pre assassination, post assassination and post election era. It is a quantities as well as qualitative study. And at the same time will measure the Favorable, Unfavorable and neutral point of view regarding research topic. According to research hypothesis the parties and their popularity are variables. Popularity is independent variable and political parties are dependent variables.

\section{Sample size}

Total time period selected as sample is six month from 18 October 2007 to 18, April 2008.it is further divided into three sets.

1.18 October, 2007 to 27 December 2007 (pre assassination era)

2.28 December, 2007 to 18 February, 2008 (post assassination era)r

3.19 February .2008to 18, April, 2008.(post election era)

\section{Data collection:}

Data was collected from selected newspapers daily Express, Daily Jang and daily Express. Daily Jang and Daily Nawa-e-Waqat (from October ,18,2007 to April ,18,2008)Editorials of newspapers were the unit of analysis .

Findings:

Total coverage of election was published in 202 editorials were published in target newspapers regarding the election 2008

Daily Express 30 ,Daily Jang 76 ,Daily Nawa-e-Waqat 96

\section{A pie chart of total coverage:}

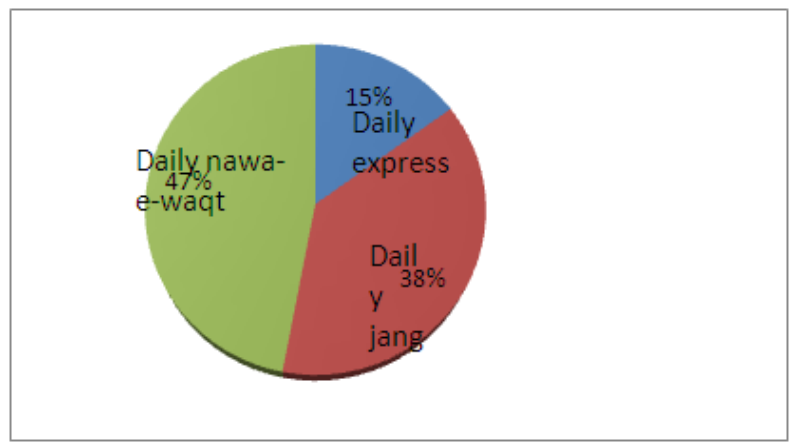

$$
\begin{aligned}
& \text { Blue }=\text { Daily Express } \\
& \text { Red }=\text { Daily Jang } \\
& \text { Green }=\text { Daily Nawa }- \text { E-Wagt }
\end{aligned}
$$

Figure 1.

Visual analysis of the pie chart indicate that daily Nawa-E-Waqt had covered most with $47 \%$ of total coverage, Daily jang is the second highest with $38 \%$ coverage and Daily Express is on third number with $15 \%$ coverage. Total time period of coverage was 184 days and these days were divided into three eras. 
Pre Assassination era (18, October to 27, December) 71 days. Post Assassination era (28, December to 18 February) 53 days. Post Election era (19, February to 18, April) 60 days.

A Bar Chart of era Wise coverage:

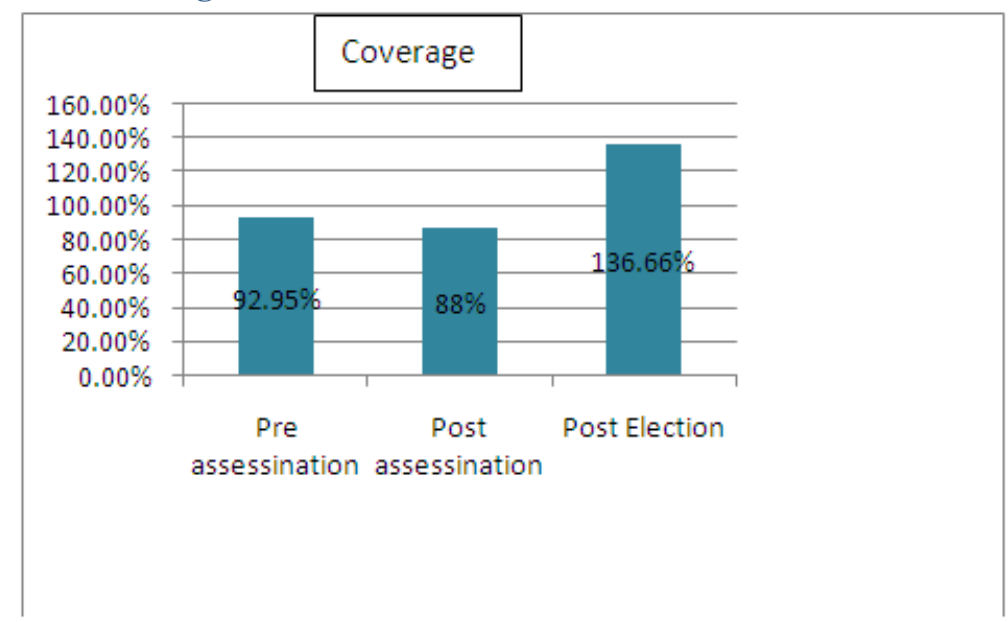

Figure 2

This bar chart shows that newspaper covered the election most $(136.66 \%)$ in post election era, pre assassination era is the second largest covered era was pre assassination era, $(92.95 \%)$ and the comparatively least covered era was the post assassination era( $88 \%)$.

\section{A Multiple Bar graph of newspaper Wise coverage}
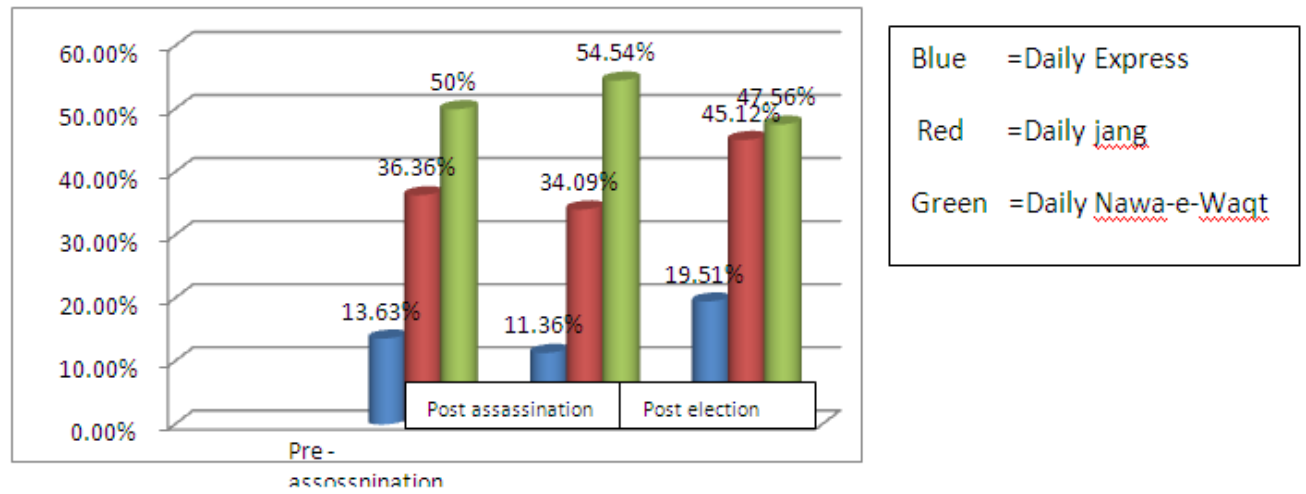

Figure 3

This multiple bar graph shows that in pre assassination era maximum coverage was $50 \%$ by daily Nawa-E-Waqt, $36.36 \%$ by daily Jang and $13.36 \%$ by daily Express. In post assassination era daily Nawa-EWaqt had covered 54.54\%. Daily Jang had covered 34.09\% and Daily express had covered $11.36 \%$. In post assassination era Nawa-E-Waqt had covered 47.56\%, Daily Jang had covered $45.12 \%$ and Daily Express had covered $19.51 \%$.

\section{Political Parties Wise coverage (Daily Express)}

\begin{tabular}{|l|l|l|l|l|}
\hline & $\begin{array}{l}\text { Pre } \\
\text { assassination }\end{array}$ & $\begin{array}{l}\text { Post } \\
\text { assassination }\end{array}$ & Post election & Total \\
\hline Pakistan people's party & 4 & 5 & 16 & 5 \\
\hline Pakistan Muslim League (Nawaz) & 5 & 2 & 4 & 1 \\
& & 0 & 3 & 8 \\
\hline Pakistan Muslim League (Quaid) & 5 & 1 & 3 & 5 \\
\hline Awami National Party & 1 & 0 & 2 & 5 \\
\hline Mutahida Majlis-e-Amal & 3 & 0 & 4 & 4 \\
\hline Mutahida Qoumi Movement & 0 & 0 & 0 & 0 \\
\hline Other Parties & 0 & & & \\
\hline
\end{tabular}


A bar graph of political party Wise total coverage by Daily Express

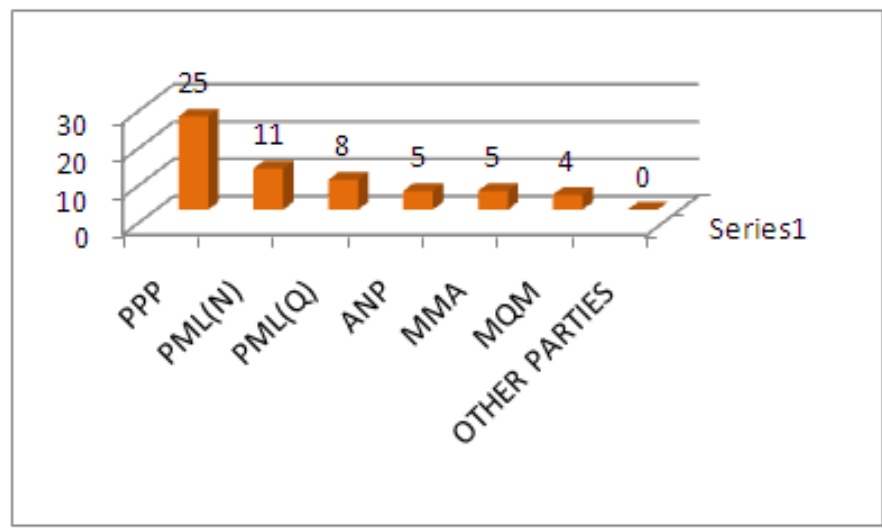

Figure 4

The visual analysis of the chart show that Daily Express had covered Pakistan People's Party Most (25timmes) Pakistan Muslim League (Nawaz) had the second largest coverage (11Times) Pakistan Muslim League (Quaid) was on third (8times) Awami National party and Mutahida Majlis-e-Amal had some popularity rate (5times) and Mutahida Qoumi Movement was the least covered Party

\section{Pre Assassination}

A bar graph of party wise coverage in pre assassination era by daily Express

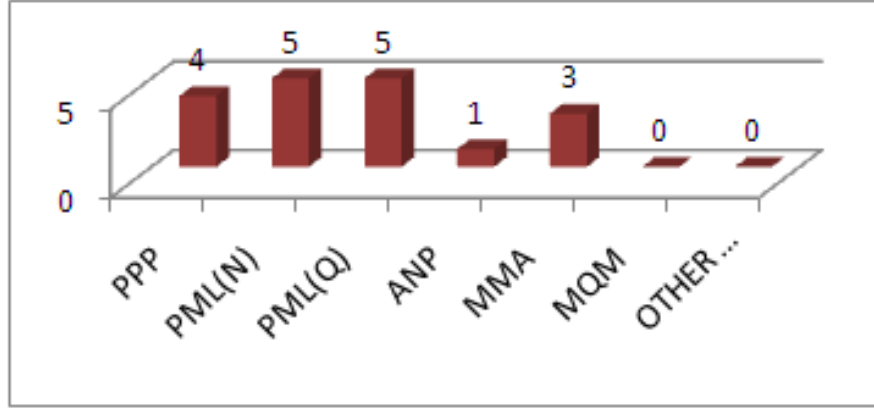

Figure 5

This graph indicates in pre assassination era Daily Express had focused on Pakistan Muslim League (Nawaz) and Pakistan Muslim League (Quaid-e-Azam) most (5 times) coverage of each. Pakistan people's party was on second number with (4 times) coverage, Mutahida Majlis-e- Amal on third with (3 times) coverage and Awami National Party on fourth with (1 time) coverage. Mutahida Qoumi Movement and other political parties had no coverage.

\section{Post Assassination}

A bar graph of party wise coverage in post assassination era by Daily Express

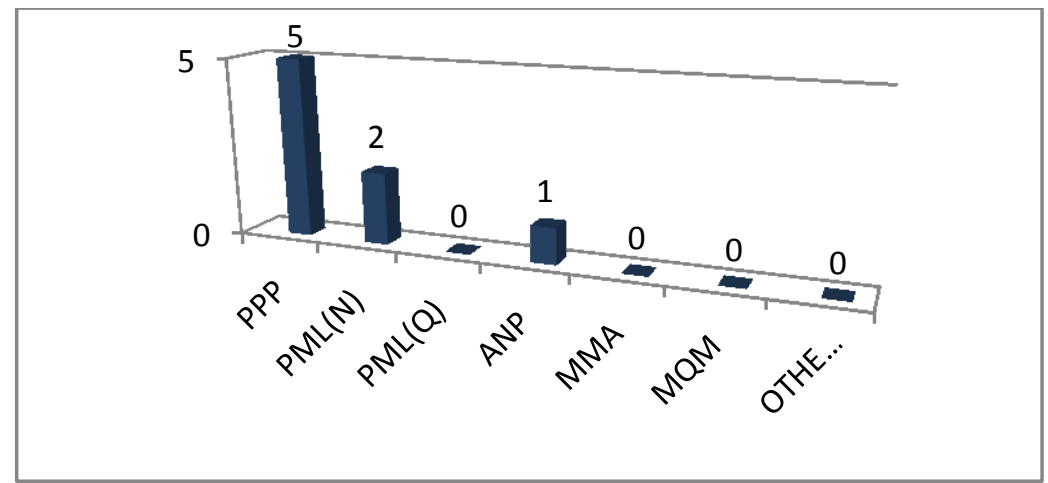

Figure 6 
This bar graph indicates that in post assassination era Daily Express had covered Pakistan People's Party most 5 times coverage, Pakistan Muslim League (Nawaz) had 2 times and Awami National Party had 1 time coverage. Pakistan Muslim League (Quaid-e-Azam), Mutahida Majlis-e-Amal, Mutahida Qoumi Movement and other political parties had no coverage.

\section{Post Election}

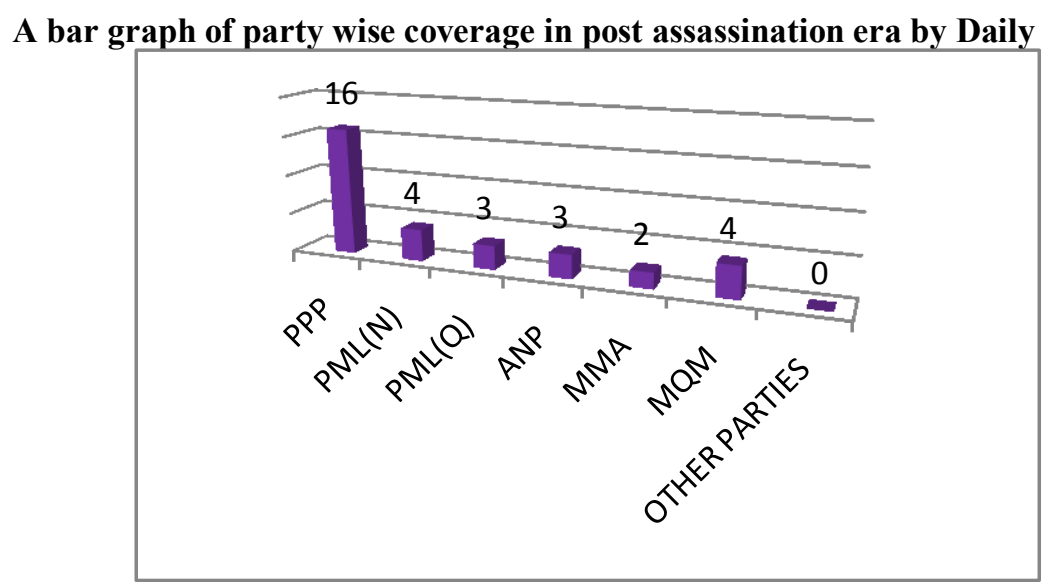

Figure 7

This bar graph indicates that Pakistan people's Party had largest coverage by Daily Express with 16 times coverage, Pakistan Muslim League (Nawaz) and Mutahida Qoumi Movement were on second number with 4 times coverage of each, Awami National Party had 3 times, Mutahida Majlis-e-Amal had 2 times and other parties had no coverage in post assassination era by Daily Express.

\section{Political Parties Wise coverage}

(Daily Jang)

\begin{tabular}{|l|l|l|l|l|}
\hline & Pre Assassination & $\begin{array}{l}\text { Post } \\
\text { Assassination }\end{array}$ & Post Election & Total \\
\hline Pakistan People's party & 12 & 9 & 45 & 66 \\
\hline Pakistan Muslim League(Nawaz) & 10 & 7 & 30 & 47 \\
\hline Pakistan Muslim League(Quaid) & 21 & 1 & 14 & 46 \\
\hline Awami National Party & 1 & 2 & 16 & 19 \\
\hline Mutahida Majlis-e-Amal & 3 & 1 & 6 & 11 \\
\hline Mutahida Qoumi Movement & 2 & 0 & 2 (PMLF) & 10 \\
\hline Other Parties & 2 PTI) & 0 & & 2(PTI) \\
& & & (PMLF) \\
\hline
\end{tabular}

Total coverage

A bar graph of political Parties wise total coverage by Daily Jang

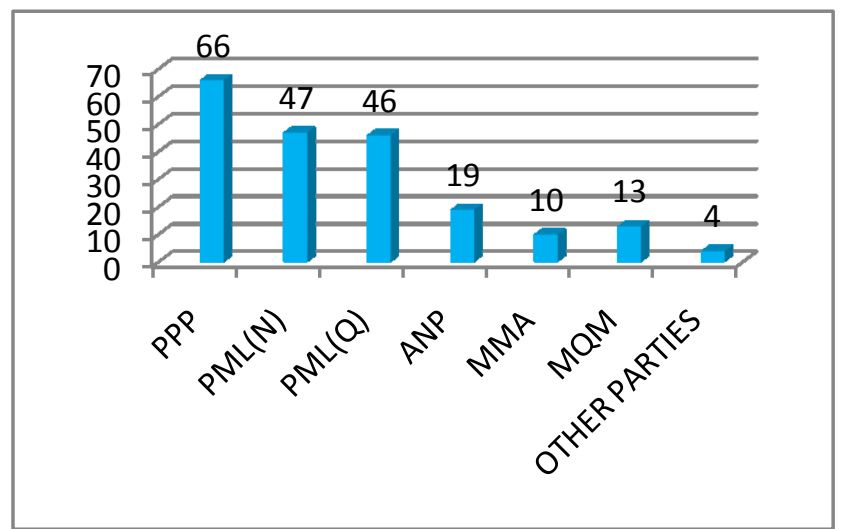

This bar graph indicates that Pakistan People's Party had coverage by Daily Jang with 66 time total coverage, Pakistan Muslim League (Nawaz) had 47 times coverage, Pakistan Muslim League (Quaid-e-Azam) had 46 times, Awami national Party had 19 times, Mutahida Qoumi Movement had 13 times, Mutahida Majlise-Amal had 10 times and other parties had 4 times total coverage in Daily Jang. 


\section{Pre Assassination}

A bar graph of political Parties wise coverage in pre assassination era by Daily Jang

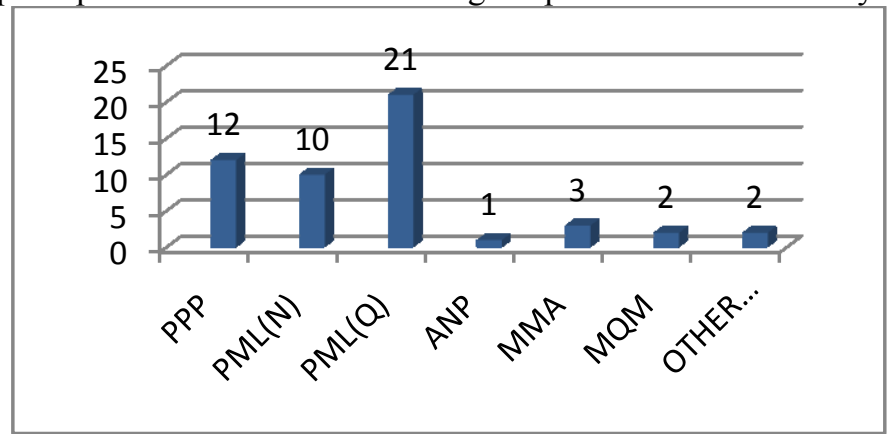

Figure 9

This bar graph indicates that Pakistan Muslim League (Quaid-e-Azam) had largest coverage with times coverage, Pakistan People's Party was on second 12 times coverage, Pakistan Muslim League (Nawaz) had 10 times coverage, Mutahida Majlis-e-Amal had 3 times, Mutahida Qoumi Movement and other political parties had 2 times each and Awami National Party had one tome coverage in pre assassination era by Daily Jang.

\section{Post Assassination}

A bar graph of party wise coverage in post assassination era by Daily Jang

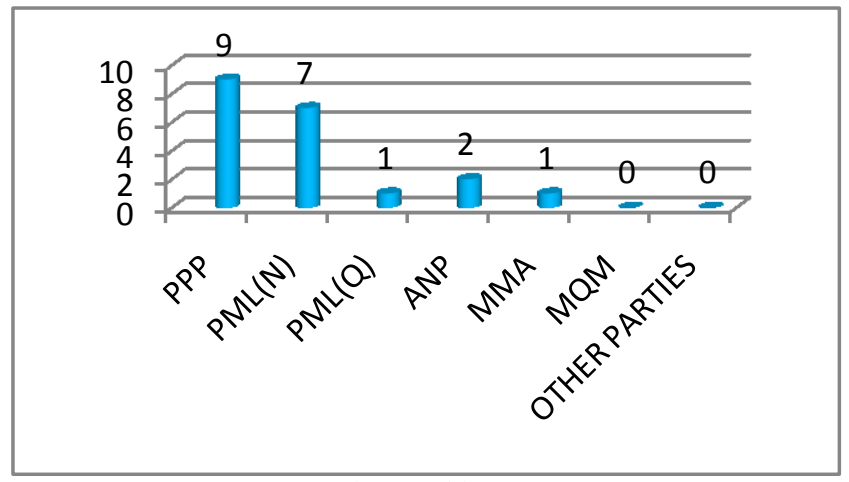

Figure 10

A bar graph indicates that Pakistan People's Party had largest coverage with 9 times coverage, Pakistan Muslim League (Nawaz) was on second with 7 times coverage, Awami National Party had 2 times coverage, Pakistan Muslim League (Quaid-e-Azam) and Mutahida Majlis-e-Amal both had 1 time coverage of each and Mutahida Qoumi Movement and other parties had no coverage in post assassination era by Daily Jang.

Post Election: A bar graph of party wise coverage in post assassination era Daily Jang

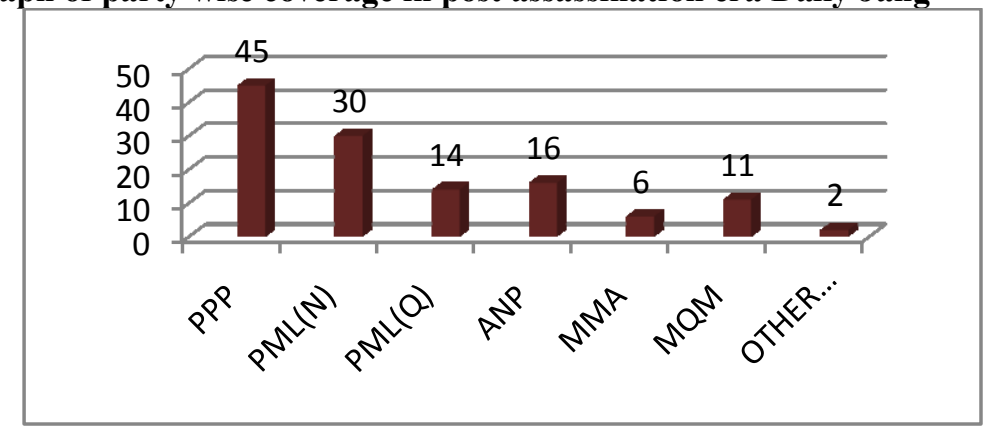

Figure 11

This bar graph indicates that Pakistan People's Party had largest coverage with 45 times coverage, Pakistan Muslim League (Nawaz) was on second with 30 times coverage, Awami national Party had 16 times, Pakistan Muslim League (Quaid-e-Azam) had 14 times coverage, Mutahida Qoumi Movement had 11 times coverage, Mutahida Majlis-e-Amal had 6 times coverage and other political parties had 2 times coverage in post assassination era by Daily Jang. 
Political Parties wise coverage

Daily Nawa-E-Waqt

\begin{tabular}{|c|c|c|c|c|}
\hline & $\begin{array}{l}\text { Pre } \\
\text { Assassination }\end{array}$ & $\begin{array}{l}\text { Post } \\
\text { Assassination }\end{array}$ & Post Election & Total \\
\hline Pakistan People's Party & 28 & 17 & 32 & 77 \\
\hline Pakistan Muslim League (Nawaz) & 25 & 16 & 31 & 72 \\
\hline Pakistan Muslim League (Quaid) & 24 & 18 & 14 & 56 \\
\hline Awami National Party & 2 & 0 & 15 & 17 \\
\hline Mutahida Majlis-e-Amal & 11 & 1 & 6 & 18 \\
\hline Mutahida Qoumi Movement & 1 & 1 & 6 & 8 \\
\hline Other Parties & 4 & 1 & 0 & 5 \\
\hline
\end{tabular}

Total coverage A bar graph of political Parties wise total coverage by Daily Nawa-E-Waq

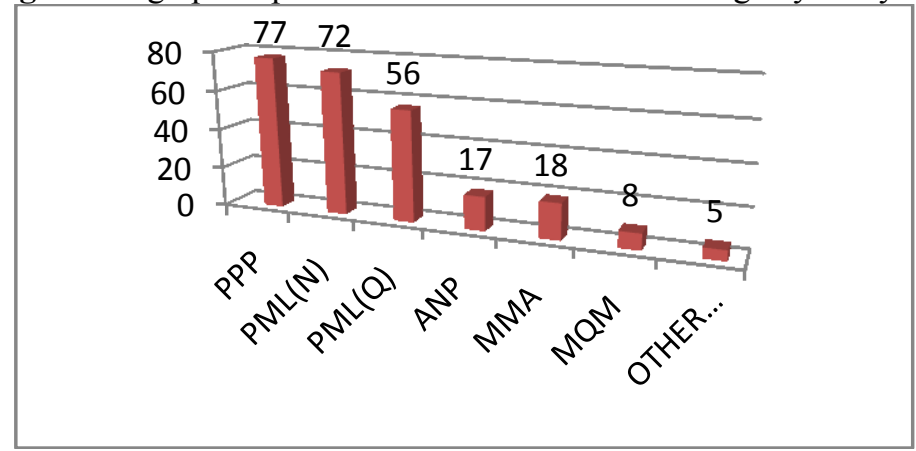

Figure 12

This bar graph indicates that Pakistan People's Party had largest coverage with 77times coverage, Pakistan Muslim League (Nawaz) was on second with 72 times coverage, Pakistan Muslim League (Quaid-EAzam) had 56 times coverage, Mutahida Majlis-e-Amal had 18 times coverage, Awami National Party had 17 times coverage, Mutahida Qoumi Movement had 8 times and other parties had 5 times total coverage in Daily Nawa-E-Waqt editorial.

\section{Pre Assassination}

A bar graph of political Parties wise coverage in pre assassination era by Daily Nawa-E-Waqt

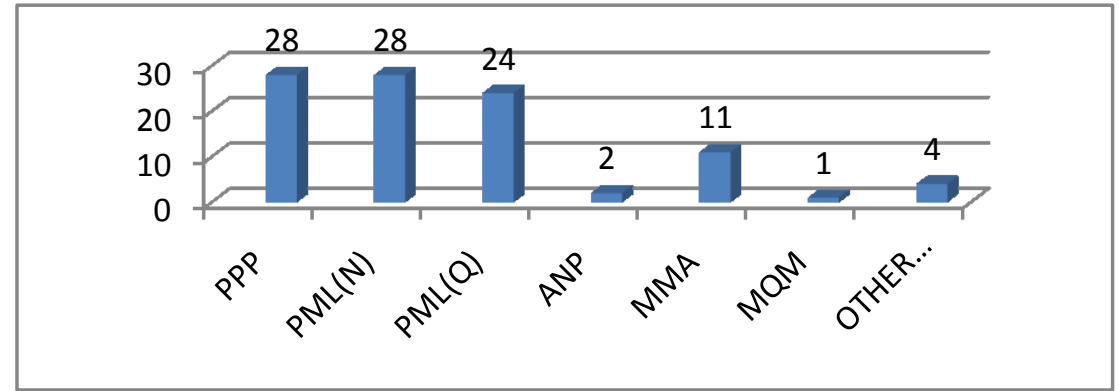

Figure 13

This bar graph indicates that Pakistan People's Party and Pakistan Muslim League (Nawaz) both had equal coverage with 28 times coverage, Pakistan Muslim League (Quaid-E-Azam) had 24 times coverage, Mutahida Majlis-e-Amal had 11 times, Awami National Party had 2 and Mutahida Qoumi Party had 2 times and Mutahida Qoumi Movement had 1 time coverage and other political parties had 4 times coverage.

\section{Post Assassination}

A Bar graph of political Parties wise coverage in post assassination era by Daily Nawa-e-Waqt.

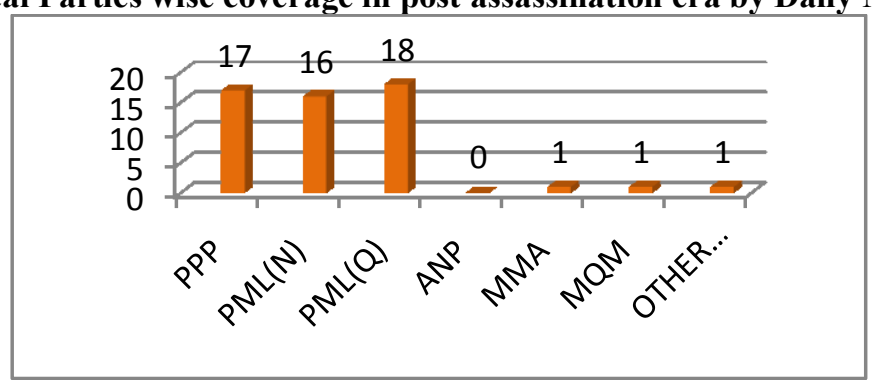

Figure 14 
This bar graph indicates that Pakistan Muslim League (Quaid-E-Azam) had largest coverage with 18 times coverage, Pakistan People's party was on second with 17 times coverage, Pakistan Muslim League (Nawaz) had 16 time coverage, Mutahida Majlis-e-Amal, Mutahida Qoumi Movement and other political parties had 1 time coverage each in post assassination era by Daily Nawa-E-Waqt editorial.

\section{Post Election}

A bar graph of political parties wise coverage in post election era by Daily Nawa-E-Waqt

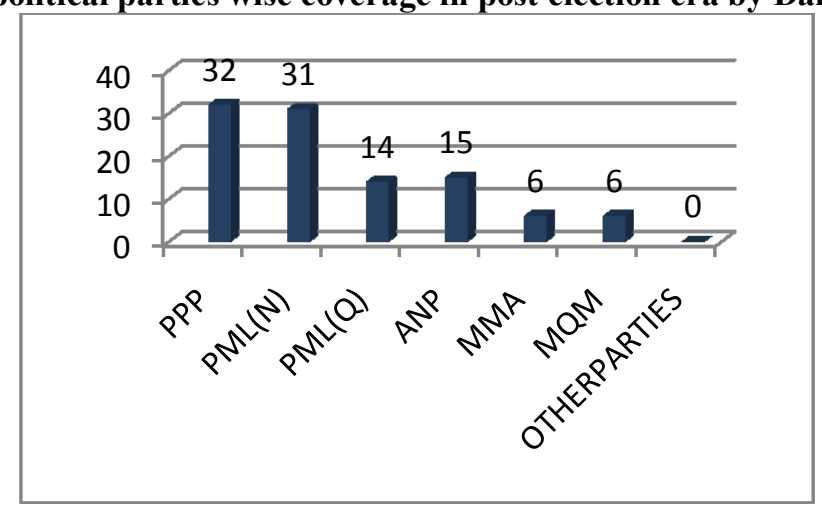

Figure 15

This bar graph indicates that Pakistan People's Party had largest with 32 times coverage, Pakistan Muslims League (Nawaz) was on second with 31 time coverage, Awami National Party had 15 times, Pakistan Muslim League (Quaid-E-Azam) had 14 times, Mutahida Majlis-e-Amal and Mutahida Qoumi Movement both had 6 time each and other political parties had no coverage in post assassination era by Daily Nawa-e-Waqt editorial.

\section{A multiple bar graph of newspaper wise political Parties total coverage}

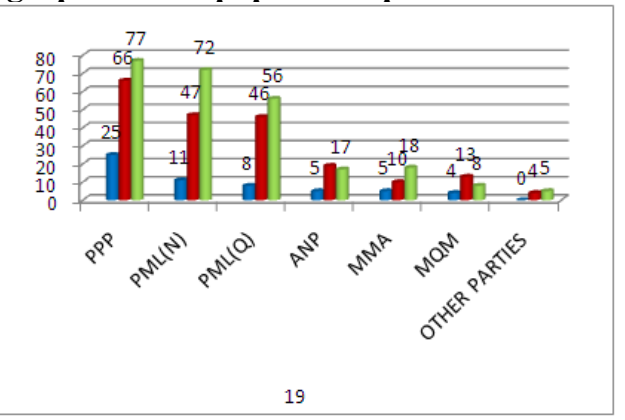

$$
\begin{aligned}
\text { Blue } & =\text { Daily Express } \\
\text { Red } & =\text { Daily Jang } \\
\text { Green } & =\text { Daily Nawa- e-Wagt }
\end{aligned}
$$

\section{Figure 16}

A visual analysis of multiple bar graph shows that Pakistan People's Party had largest coverage in all three newspapers, Pakistan Muslim League (Nawaz) was on second, Pakistan Muslim League (Quaid-e-Azam) was on third, Awami National Part was on forth, Mutahida Majlis-e-Amal was on fifth, Mutahida Qoumi Movement was on sixth number in the total coverage of political parties coverage in all three newspapers.

A Qualitative analysis of coverage with favorable, unfavorable and Neutral point of view. Pre Assassination (Daily Express)

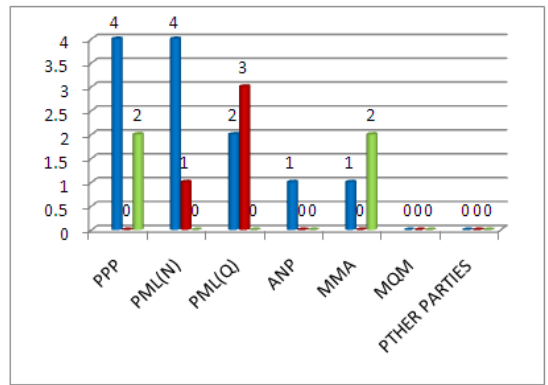

$$
\begin{aligned}
& \text { Blue }=\text { Favorable } \\
& \text { Red }=\text { Unfavorable } \\
& \text { Green }=\text { Neutral }
\end{aligned}
$$

Figure 17 


\section{Post Assassination}

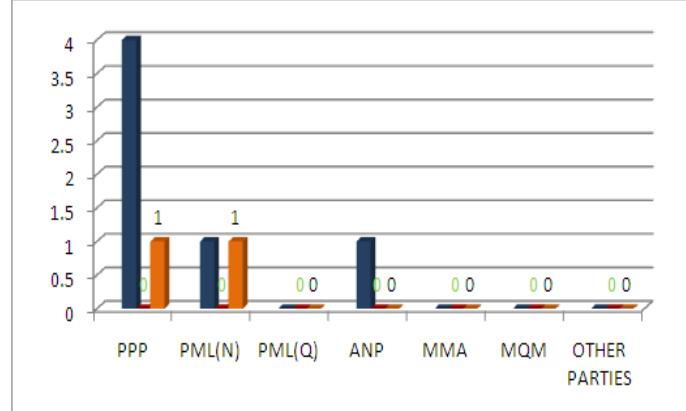

Blue $=$ Favorable

Red = Unfavorable

Orange $=$ Neutra

Figure 18

Post Election Figure 19

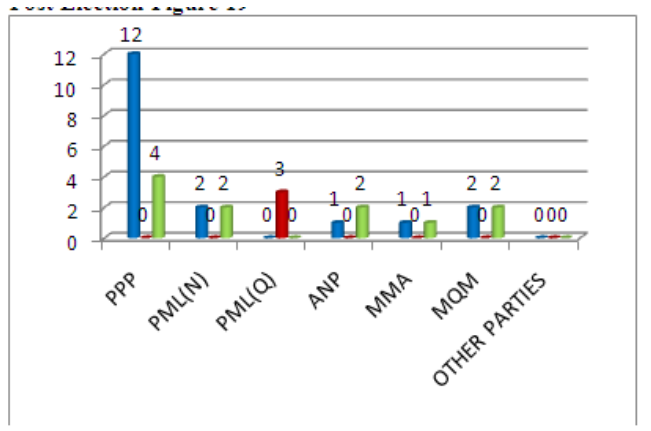

Blue = Favorable

Red = Unfavorable

Green $=$ Neutral

Figure 20 Daily jang Pre Assassination

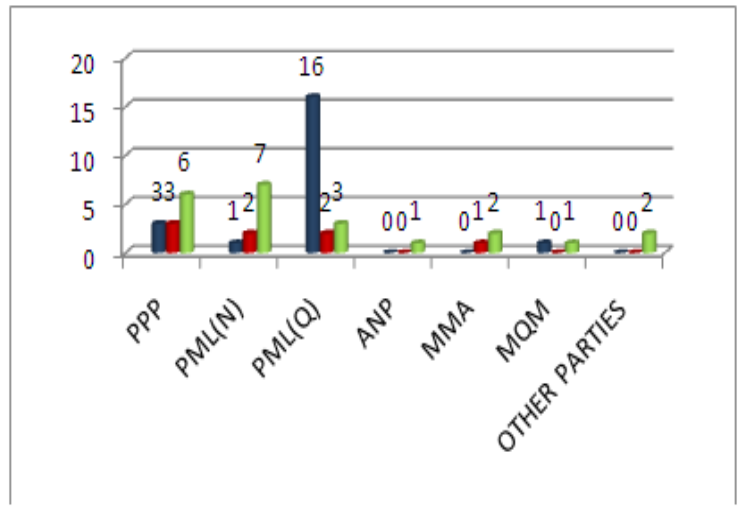

$$
\begin{aligned}
& \text { Blue }=\text { Favorable } \\
& \text { Red }=\text { Unfavorable } \\
& \text { Green }=\text { Neutral }
\end{aligned}
$$

Figure 21 Post Assassination

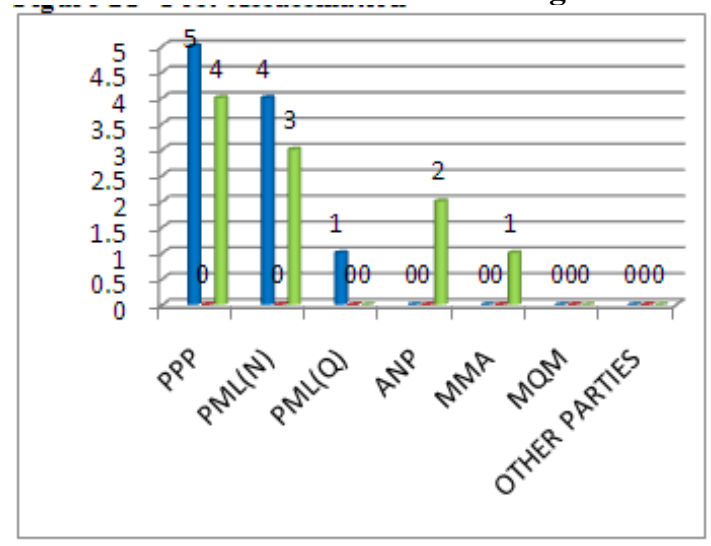

$$
\begin{aligned}
& \text { Blue }=\text { Favorable } \\
& \text { Red }=\text { Unfavorable } \\
& \text { Green= Neutral }
\end{aligned}
$$

Post Election Figure 22 


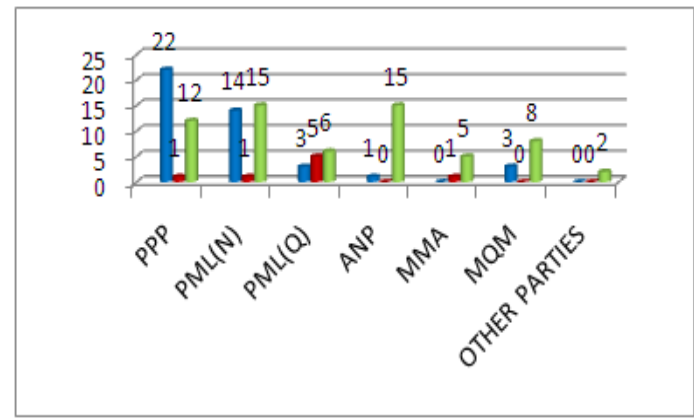

Blue $=$ Favorable
Red $=$ Unfavorable
Green $=$ Neutral

\section{Daily Nawa-E-Waqt}

Pre Assassination Figure 23

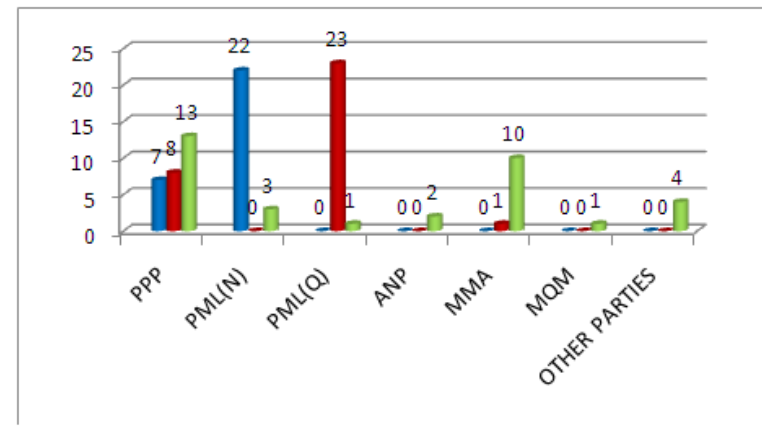

$$
\begin{aligned}
& \text { Blue }=\text { Favorable } \\
& \text { Red }=\text { Unfavorable } \\
& \text { Green }=\text { Neutral }
\end{aligned}
$$

\section{Post Assassination Figure 24}

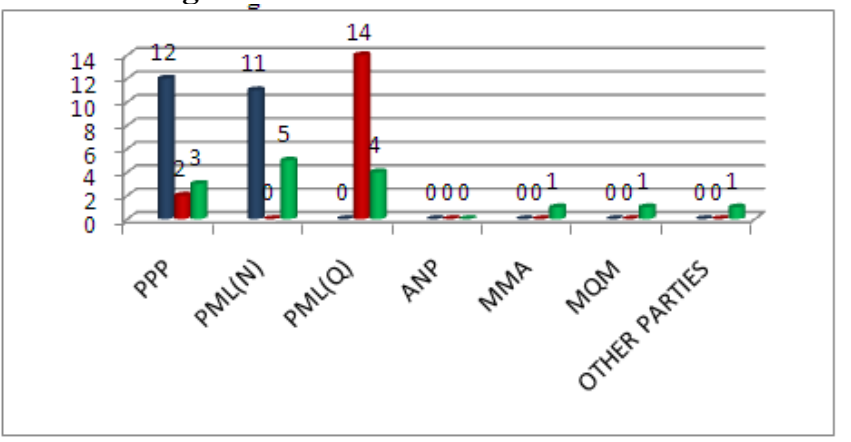

$$
\begin{aligned}
& \text { Blue = Favorable } \\
& \text { Red = Unfavorable } \\
& \text { Green = Neutral }
\end{aligned}
$$

\section{Post Election Figure 25}

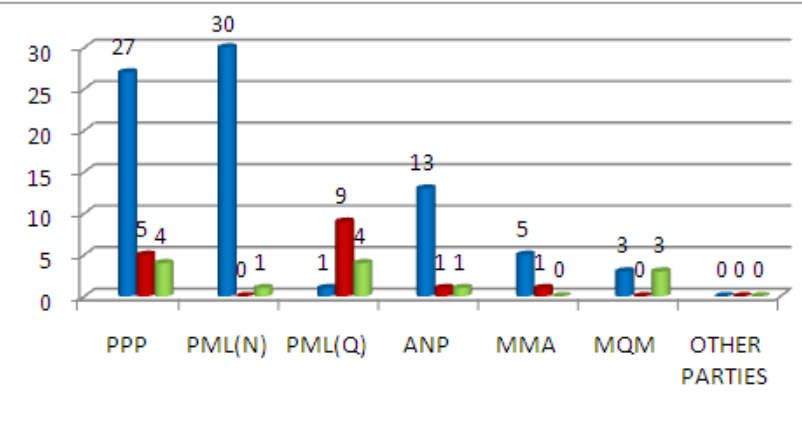

$$
\begin{aligned}
& \text { Blue }=\text { Favorable } \\
& \text { Red }=\text { Unfavorable } \\
& \text { Green }=\text { Neutral }
\end{aligned}
$$

\section{Discussion}

The present study was aimed to make a comparative analysis of editorial treatment by Urdu press of Pakistan, regarding election 2008.with special reference to Benazir Bhutto's assassination. Content analysis shows that in target newspaper of the sample time frame had published 202 editorials in the news paper. Daily express had published 30 editorials. Daily Jang had published 76 and daily Naw-e-Waqa 96 editorials on election 2008. The sample time for study was six month were divided in to three phases. The comparative analysis of era wise coverage has proved the first hypotheses which was related to the Pakistan people's Party. Pakistan Muslin league (Nawaz)and Pakistan Muslim league (Quaid -e-Azam)were most popular political parties in editorial coverage before Benazir Bhutto assassination(fig;6.9 and 13) 
As well as the qualitative analysis also proved that in all of the target news paper these parties were most popular parties(17,20 and 23)the study of editorials in pre-assassination era also proved the second hypothesis that is: All the news papers understudy had diverse opinion about popular party in pre assassination era.

The editorial study of the second phase of research (post assassination)has proved the third hypothesis, which was related to popularity of Pakistan people's party had increased after the Benazir Bhutto o 's assassination (fig 18,21,24)

The study partially proved the forth hypotheses: That was Pakistan Muslim (Q) had lost its popularity in post assassination of era. News paper editorials had covered Pakistan Muslim league (Q)But under unfavorable frame, here media had set public agenda pro Pakistan people's party and anti Pakistan Muslim league (Q)The study of newspapers editorials on third phase (post election era)indicates that after election ,news papers used favorable frame again for Pakistan people's party who got majority in parliament. (fig 19,22,25)

this study also proved the fifth hypothesis, which was "all the parties with minority preferred to join Pakistan people's party " Pakistan Muslim league (N), Mutahida Qumi movements and Mutahida Majilis -eamal had supported Pakistan people's party in the parliament and formed a government with co-co-election .Pakistan Muslim league (Q) was the only major party in opposition.

\section{Conclusion}

The result of the research clearly shows that newspaper's policy has a great affect on public opinion. People rely on the information provided by newspaper and react according to these information. Benazir assassination was a very important national incident; it had affected the election 2008 result strongly) News paper editorials are the reflection of newspaper's policy. The research is an analysis of editorial treatment. In pre assassination era all the newspapers had a different agenda but after Benazir assassination) the result of 2008 election are a reflection of the media agenda. The winning political parties were those parties who had a larger coverage in newspapers editorials before election 2008.people had casted their vote against those parties who had less or negative coverage in newspapers.

\section{References}

[1]. Chang, yu-li,and chang,kuang -kuo. (2003) '"world editorials on the September 11 terrorist attacks integrating news flow analysis in international communication and framing analysis"

[2]. Election (2008) "Benazir Factor May affect the results".

[3]. www.elections.com.pk/articledetails.php?id=313. Sharma Delhi "Benazir, s assassination, implication for Pakistan democracy"

[4]. http://www.ipcs.org/article/indo-pak/benazirs-assassination-implications-for-pakistans-democracy-

[5]. Richardson,John and Lancendorfer Karen (2004)' 'The diversity frames :A different views of Affirmation Action in news media and news room",

[6]. http://www.allacademic.com/meta/p_/p112677-30 2457.html

[7]. Sharma Delhi "Benazir, s assassination, implication for Pakistan democracy".

[8]. http://www.ipcs.org/article/indo-pak/benazirs-assassination-implications-for-pakistans-democracy-2457.html

[9]. Somia Shakir .comparative analysis of editorial treatment on Indo Pak conflicts, in Daily Dawn and the Nation: “A war and Peace Journalism"

[10]. Sikanku ,Etse (2010)' framing barrack Obama 's first visit to Africa as president: A comparative analysis of Africa and nonAfrican news coverage"

[11]. http://citation.allacademic.com/meta/p_mla_apa_research_citation/4/3/3/1/1/p433117_index.html >

[12]. SAN Report (2008) "Benazir factor may affect the results". http://san-pips.com/PIPS-SAN-Files/SAN-Pakistan/SAN-PAKArticle52/San-Pak-Main-A52-D.asp

[13]. Scheufele ,Dietram A.(1999) "'Framing as a theory of media effects "' journal of communication" 